\title{
Testimonies in The Testaments by Margaret Atwood: Images of Food in Gilead
}

\begin{abstract}
In The Testaments, Margaret Atwood takes readers deeper into her dystopian world of Gilead, also through the imagery of food and eating. The oppressive patriarchal regime enforces its power through dietary restrictions, reducing women into edibles. The Testaments (2019), moreover, creates the impression of a highly individual and authentic narratorial perspective. Thus, Atwood's characters' daily lives in a nightmarish theocracy are illustrated with images of dystopian food that reflect the limitations, constant control, and abuse of human rights in the Republic of Gilead. This article explores how Atwood employs the literary form of testimony to create fragments of individual lives in a dystopia brought closer to us through food metaphors and metaphors of cooking, or rendered shocking through metaphors of cannibalism. Since food (and lack of food) has emotional as well as political significance, it pervades the testimonial literature of oppressive regimes.
\end{abstract}

Keywords: Margaret Atwood; The Testaments; The Handmaid's Tale; food; cannibalism; power politics; dystopia; testimony; witness literature; confessional writing

\section{Pričevanja v romanu Testamenti Margaret Atwood: Podobe hrane v Gileadu}

\section{POVZETEK}

Margaret Atwood v romanu Testamenti bralca popelje še globlje v distopični svet Gileada - tudi s pomočjo podobja hrane in prehranjevanja. Tiranski patriarhalni režim namreč uveljavlja svojo oblast s prehranskimi omejitvami, s čimer ženske degradira v hrano. Roman Testamenti (2019) poleg tega ustvari vtis močno individualizirane in avtentične pripovedne perspektive. Vsakdanja življenja romanesknih oseb v strašljivi teokraciji so tako prikazana s podobami distopične hrane, ki odseva omejitve, stalen nadzor in zlorabo človekovih pravic v Gileadu. Članek raziskuje, kako Margaret Atwood z uporabo literarne oblike pričevanja ustvari izseke individualnih življenj v distopični družbi, ki nam jih približa skozi metafore hrane in njene priprave oziroma nam jih prikaže kot strašljive skozi metafore kanibalizma. Hrana (in njeno pomanjkanje) ima čustven in političen pomen, zato je pogosto uporabljena $\mathrm{v}$ pričevanjski literaturi, ki govori o zatiralskih režimih.

Ključne besede: Margaret Atwood; Testamenti; Deklina zgodba; hrana; kanibalizem; politika moči; distopija; pričevanje; pričevanjska literatura; izpovedna literatura 


\section{Introduction}

Food is one of the key thematic threads that readers can grasp through the labyrinthine hybrid genres in Atwood's speculative fiction novels, which move seamlessly from dystopian to confessional writing, testimony, and memoir. In The Handmaid's Tale (1985) and The Testaments (2019), food can be used as a means of subversion, giving individuals at least some power over lives and bodies that are owned and controlled by the state. In Gilead, a cruel power politics of "who is entitled to do what to whom with impunity; who profits by it; and who therefore eats what" is dramatically exaggerated (Atwood 1995, 19).

The Testaments adopts cooking metaphors and images of food to underline how women are deprived of their human rights and status by the dystopian Republic of Gilead, which views them as nothing but a tool for reproduction. Images of food, cooking, and eating vividly convey the dreariness and brutality of life under an oppressive political regime. Food- and eating-related memories in testimonies communicate the unspeakable experience of Gilead. As Carole Counihan argues, "[f]ood constitutes language accessible to all" (1999, 19). In The Testaments, testimonies of Gileadean life and food convey a great deal about Gilead, its dehumanizing sexual politics, gender relations, and the enslavement of its citizens. Gileadean testimonies show how the state portions and poisons women as well as food, despite its utopian promises. The underlying theme of hunger reflects the fragmentation and isolation of human beings. ${ }^{1}$ This analysis of food in The Testaments builds on theoretical concepts of food presented in studies by Warren Belasco (2008), Deborah Lupton (1996) and Elspeth Probyn Carnal (2003).

In Bite Me: Food and Popular Culture, Fabio Parasecoli demonstrates that issues associated with food form a pervasive influence, and creative fields such as art, film, media, and literature draw on these as a source of significance. ${ }^{2}$ Food has recently become a focus of interest in literary and cultural studies. The study of food in literature, gastrocriticism, examines how dietary choices define the self. As Maria Christou points out, the field tends to approach questions of identity through three categories: historical context, national and political affiliation, and gender. She argues that gastrocritical exploration is "the investigation of food in relation to wider contexts, which almost invariably leads to the exploration of certain historico-geographical, national, political, or gendered identities" (Christou 2017, 7). Food allusions help the author of dystopias illustrate a society's power, gender, and class struggles: What food is available, and for whom? Who produces and who serves the food? What are the typical food rituals, and how do food shortages illustrate the physical, sociological and/or psychological dysfunctions of the society?

Food studies is a holistic, interdisciplinary field that uses anthropological, sociological, historical, and cultural approaches to food.

2 There are numerous books on food and literature, including Allison Caruth's Global Appetites: American Power and the Literature of Food, 2013; Sarah Sceats's Food, Consumption, and the Body in Contemporary Women's Fiction, 2000 with a special chapter on food in Atwood's novels (94-125); Tamar Heller and Patricia Moran's Scenes of the Apple: Food and the Female Body in Nineteenth-and Twentieth-Century Women's Writing, 2003, which discusses food and feminine identity. Maria Christou's latest book, Eating Otherwise, discusses the philosophy of food in 20th-century literature. It includes a chapter on food in Atwood's dystopias. 
As Counihan suggests, "food is a prism that absorbs and reflects a host of cultural phenomena. An examination of food ways-behaviours and beliefs surrounding the production, distribution, and consumption of food-reveals much about power relations" $(1998,6)$. In The Testaments, food allusions in the individual testimonies help the reader to see through the (seeming) plenitude of food in the oppressive regime. Food and lack of food often occur in testimonies: inedible food, and images related to food and hunger proliferate in Holocaust narratives. ${ }^{3}$ Communist regime testimonies often feature food shortages, governmental regulation of consumption, and queuing for food supplies (Burrell 2003, 189). In a similar vein, food disorders and changes in eating (and sleeping) patterns often appear in rape and sexual trauma testimonies (Ross 2009, 211). Thus, witness narratives about food might lend a materiality to the impossible task of "the transmission of the untransmittable" (Radstone 2001, 61). This important link between food and testimony is examined here.

The main story line in Atwood's much-awaited sequel to The Handmaid's Tale (1985) is a spy thriller about an infiltrator inside Gilead cooperating with the Mayday resistance to destroy the theocratic regime from the inside. Set in second-generation Gilead, fifteen years later, it leaves Offred behind: we hear only a couple of words from her. Atwood replaces her legendary voice with three other female voices. In "Why it took Margaret Atwood 30 years to find the right voice for a sequel to The Handmaid's Tale," Atwood explains that she knew she could not recreate Offred's voice: "It would have been a horrible mistake to have attempted it" (Ackew 2019). Instead, the story of The Testaments is narrated by three female voices: by baby Nicole, a.k.a. Daisy, now a teenager living in Canada. After learning her true identity, she decides to work with the Mayday resistance. Another perspective is given by Agnes Jemima, Offred's first daughter, who was taken away from Offred and her husband Luke after their traumatic attempt to escape to Canada. The girl has been living in Gilead with Commander Kyle and Tabitha, her foster parents. She is being brought up to become a Commander's wife. The third voice belongs to Aunt Lydia, the indoctrinator and cruel enforcer, who has collaborated with the Gileadean regime. Now, she is taking Gilead down.

\section{Testimonies and Testaments}

Despite the first Gilead novel, The Handmaid's Tale, being titled as a "tale," a word suggestive of fiction, and the doubts expressed by Professor Pieixoto at the end, Offred's first person narration is meant to feel like a direct reproduction of everyday life under an oppressive dystopian regime. As Offred gets dressed, eats, walks from shop to shop, from Birth Day to Salvaging, from her room to the Commander's office and back to Cora and Rita's kitchen, the reader moves with her and hears her internal commentary. Her words have the weight of emotional truth. Offred's restricted vision captures many blatant abuses of power and much torture, violence and surveillance directed against women, though the novel points to even more being hidden behind the wings of her bonnet. The Testaments broadens the view of Gilead through another three individual testimonies. One of the narratives, the memoirs of Aunt Lydia, takes readers close to the apex of Gilead's monstrous power structure. Even so, as the name suggests, the genre is again that of witness literature or testimonial literature.

For more on food and deprivation, see Susanne Luhmann, "Managing Perpetrator Affect: The Female Guard Exhibition at Ravensbrück" and Wilhelmine Haferkamp "Motherhood Times Ten and Food To Spare" (1995). 
Atwood has described the Gilead novels' genre with reference to witnessing. In "Margaret Atwood on What The Handmaid's Tale Means in the Age of Trump," she highlights her use of the literary form of the literature of witness: "Offred records her story as best she can; then she hides it, trusting that it may be discovered later, by someone who is free to understand it and share it. This is an act of hope: Every recorded story implies a future reader" (Atwood 2017). Atwood refers to the accounts left by people bearing witness to the tragedies of history they have experienced. As Axel Gelfert argues: "although the act of bearing witness is usually an individual one, it contributes to what is sometimes called 'sensemaking' - the social activity of giving meaning to collective experiences" (Gelfert 2014, 17). Atwood's witnesses survive the nightmarish dystopia of Gilead and share their experience with us.

Witness literature or testimonial literature primarily deals with experiences such as the two World Wars, genocides, the Communist regimes, the Holocaust and an "unprecedented number of disastrous events on a mass scale that wreaked havoc" (Felman 1992, 2). However, it is not only the occurrence of terrible events that makes the present era a testimonial era; it is the specific mode of narrativization of those traumas. Writers of testimonies offer a counter-narrative to the dominant official narrative produced by their oppressors. The genre of testimonial literature thus cannot be clearly defined; it is implicitly a hybrid form because " $[t]$ rauma invites distortion, disrupts genres or bounded areas, and threatens to collapse distinction" (LaCapra 2014, 96). Writing/narrating thus becomes an act of survival. Several critics argue against regulating testimonies and setting genre boundaries. According to Julian Wolfreys, "[t] estimony, in order to be such, cannot be calculated, for every testimony must respond to the singular specificity of the traumatic experience [...] Testimony is irreducible to some concept or figure, some genre or species of narrative within historical narrative or literature" $(2015,130)$.

What makes testimony different from other forms of autobiographical writing? It is the tough core of the narrative. The content of testimony is centered around a traumatic event: as Lawrence L. Langer puts it: "the content of a written survivor memoir may be more harrowing and gruesome than most autobiographies" $(1993,41)$. However, most testimonies also follow a typical autobiographical chronology. Testimonies are inherently hybrid, participating in multiple genres that criticize, resist and oppose any regime that uses harsh categorization, intrusive policing and brutal repression to support a monological narrative.

We understand the Holocaust diary of Anne Frank and the oral histories collected by Svetlana Alexievich ${ }^{4}$ as examples of witness literature: even young girls like Anne Frank, children in Alexievich's Last Witnesses or Atwood's Agnes can contribute to the truth of the historical record. Even the silent voices can scream their stories if there is someone who listens. Even if it is that rather pompous scholar, Professor Pieixoto, who gives the ironic epilogue to both The

Svetlana Alexievich interviewed Russian and Belarussian women about their World War II experience (War's Unwomanly Face, 1985); She also collected first-hand accounts from the war in Afghanistan (Boys in Zinc: Soviet Voices from the Afghanistan War, 1991); and oral histories of men and women survivors or the Chernobyl nuclear catastrophe (Chernobyl Prayer: A Chronicle of the Future, 1997. Alexievich interviewed the generation who had experienced war as children: Last Witnesses: Unchildlike Stories, 1985. Food functions to trigger their memories. All the witnesses mention lack of food, hunger, and inedible food as traumatic. 
Handmaid's Tale and The Testaments. In Writing History, Writing Trauma, Dominick LaCapra argues that testimonies "provide something other than purely documentary knowledge," as they show us the emotional charge of the trauma on the witness. "Testimonies are significant in the attempt to understand experience and its aftermath, including the role of memory and its lapses, in coming to terms with - or denying and repressing - the past" (2014, 86-87).

One of the definitions of Gilead, according to the Bible dictionary, is "heap [of stones] of witness" (Genesis 31:47-48). In testifying to what they have witnessed, Offred, Lydia, Daisy, and Agnes speak against the monological story of the novel's oppressive regime. Although this regime silences women's voices, they are determined to record and tell their witness stories. In line with this, the title of the novel, The Testaments, points to several possible concepts. As Atwood explains in Time: "It has several different meanings: last will and testament, Old and New Testaments. And what does a witness give? A testimony, but also a testament [...] So it's those three: the witness, the will and 'I'm telling you the truth"' (Feldman 2019). The Republic of Gilead follows the exterminatory practices of other totalitarian regimes such as the Nazis and Soviet Communists: erasure of data, burning of books and documents and executions of their opponents, all of which force later generations to rely more upon alternative sources for evidence of their totalitarian rule. Testimonial literature, by using multi-voiced, multi-perspectival, and in the case of Atwood, multi-generic texts, produces alternatives to the official history of Gilead that looms in the novels' background. Aunt Lydia acknowledges the process of totalitarian rewriting of history in her memoir: "The corrupt and blood-smeared fingerprints of the past must be wiped away to create a clean space for the morally pure generation that is surely about to arrive. Such is the theory" (Atwood 2019, 4). Against this, the credible testimonies undermining official totalitarian narratives are immensely valuable; it is an authentic human experience. As Gelfert points out, "Historically, testimony has been associated with the communication of knowledge based on the experiences of others" (2014, 24).

Atwood's oeuvre transgresses genre boundaries, and her blurring of the boundaries between testimony and other kinds of autobiographical writing produces a persuasive, hybrid writing. Discussing the generic specifics of The Testaments, we encounter a fundamental question affecting this type of autobiographical narrative - whether fictionalized or not. How much should we rely on a narrator to be telling the truth? Offred's testimony is challenged by subsequent historians of Gilead; moreover, we know that Offred strategically manipulates the reader, omits some displeasing truths and offers several possible versions of events. In The Handmaid's Tale, Offred tells us what her experiences in Gilead look like in her memory. Such testimony is not what an objective historian who possessed all the facts would write, but it can sometimes be the only means of access to the truth. Testimonial literature is narrated by a marginalized witness and draws attention to the complex interaction of memory and revision involved in the process. Atwood brings together elements of autobiographical genres: the diary, testimony, witness narrative, and survivor narrative. She produces a chorus of witnessing voices. The Testaments suggests that Gilead cannot impose a single, totalitarian vision, even when it bans all reading and writing and uses television for brainwashing.

In the case of The Testaments, where there are three narrators, the intersubjective process between the narrator(s) and the reader shifts from evaluating, proofreading, cross-checking 
and verifying facts to sympathy, understanding, and, possibly, self-reflection. These stories authenticate each other and make a strong, immersive narrative that is compelling and emotive. In Testimony: Crises of Witnessing in Literature, Psychoanalysis, and History, Shoshana Felman and Dori Laub (focusing primarily on Holocaust writing) make a difference between testimony and autobiography: "A 'life testimony' is not simply a testimony to a private life, but a point of conflation between text and life, a textual testimony which can penetrate us like an actual life" $(1992,2)$. Atwood's novel thus advocates the power of female testimony: the multiple perspectives overlay each other and create a palimpsest of (historical) memory of the cruelty and violent abuse of human rights by the Republic of Gilead. The palimpsest is a crucial term in describing Gilead, since the state rewrites its history and architecture, as well as the identities and human rights of its citizens. On the formal level, Atwood uses the hybrid genre of testimony to signal the complexity of her work as an open and multilayered palimpsest. If Offred's lone testimony seemed unreliable and was rewritten by Professor Pieixoto, now we can compare it against three other women's perspectives. Since there are three individual witnesses (four with Offred), their individual testimonies create a credible collective mosaic. In Testimony: Crises of Witnessing in Literature, Psychoanalysis, and History, Felman and Laub argue that " $[\mathrm{t}]$ he testimony to the trauma thus includes its hearer, who is, so to speak, the blank screen on which the event comes to be inscribed" $(1992,57)$. Through the testimonies of Offred, Lydia, Daisy and Agnes, we empathize with their traumatic experiences and we can begin our own self-reflexive process.

Aunt Lydia's memoir and the transcripts of Witness Testimony 369A (Agnes) and 369B (Daisy) give us glimpses into everyday life in Gilead. The food they eat, their eating practices and food shortages illustrate the omnipresent control and power hierarchies of Gilead. These everyday accounts are what Gelfert calls mundane testimonies: "their name, their age, line of work or what they had for breakfast" $(2014,20)$. However, besides these mundane matters, the witnesses give us their specific knowledge based on their position in the society. The two teenage girls' voices are well-contrasted: Agnes's humble, God-fearing manners are juxtaposed with Daisy's foul-mouthed grunge-style speech patterns. The Testaments ends with the Thirteenth Symposium on Gileadean Studies in 2197, where we learn about the fall of Gilead, which may have been instigated by Offred's testimonial tapes, Aunt Lydia's testaments (although these are doubted by some Gilead Studies scholars), and the Mayday resistance. In the second novel, Atwood focusses less on specific cases of brutality by the oppressive regime and more on how the narrators' life experience and individual temperaments shape their characters, their reactions, and how they deal with their (traumatic) situations. Reading the three testimonies together and alongside Offred's gives readers insight into a theocratic regime in which individuals are melted into a uniform mass.

However, for Agnes and Daisy, the story is more about searching for their identities, families and roots than about recording the cruel crimes of Gilead: Daisy learns that her life as the daughter of the owners of a second-hand clothes shop is a sham, and Agnes uncovers the falsehood behind Gilead's narratives and that the Gileadean Bible has been heavily rewritten to serve the corrupt leaders. Her testimony is more a young girl's diary of her childhood, school and family life than an exposé of Gileadean misogynistic politics. As is familiar from Atwood's earlier fiction (Cat's Eye, for instance, girls must address their past before entering 
their full adult roles). Since Daisy and Agnes are teenagers, their trickery, heroism and loyalty to each other constitute a victory not only over a patriarchal and misogynistic regime, but also over the mistrust, jealousy, and the other perverse ways women betray other women in The Handmaid's Tale. In The Testaments, Becka (Aunt Immortelle) commits suicide to buy time for Daisy and Agnes. Under Aunt Lydia's secret coaching, the girls bring down the monstrous system by relying on each other and some very old spying techniques (microdots, codes, and bribery): "We could have been swept out with the tide and ended up in South America, but more likely picked up by Gilead and strung up on the Wall. I'm so proud of Agnes - after that night she was really my sister" (Atwood 2019, 397). Atwood balances the treachery, jealousy and hatred shown in The Handmaid's Tale with values of female friendship and sisterhood.

Aunt Lydia writes another layer into the palimpsest of Gileadean witness narrative. She testifies to her actions, admitting that she has "buried a lot of bones, now [she's] inclined to dig them up again - if only for your edification, my unknown reader" (Atwood 20019, 4-5). She also defends her life choices in a banal poetic echo: "Two roads diverged in a yellow wood, and I took the one most travelled by. It was littered with corpses, as such roads are. But as you will have noticed, my own corpse is not among them" (Atwood 2019, 66). She tells us (and herself) that she had to lead to survive. Before Gilead, she was a family court judge, and an educated woman who contributed to charity. Then she is arrested, taken to a stadium that has become a detention center where she witnesses cruelty, executions, and the disappearance of other women lawyers. She is imprisoned in an isolation cell; hungry and beaten three times, she is released and given the choice to collaborate with the new regime:

[...] three men came into my cell without warning, shone a glaring light into my blinking purblind eyes, threw me onto the floor, and administered a precise kicking, and other attentions. The noises I emitted were familiar to me: I had heard them nearby. I won't go into any further details, except to say that Tasers were also involved. (Atwood 2019, 148)

Aunt Lydia puts on the brown uniform and chooses to wield a Taser rather than be tasered.

Aunt Lydia's testimony puts emphasis on the events and persons she has witnessed. She focuses on the historical importance of the political system of Gilead, and especially on its corrupt leaders. Where Offred could only doubt the official TV reports, Aunt Lydia testifies to Gilead's isolation, border controls, technology failures, and the bureaucratic labyrinths of a (barely) functioning state. Many references take us back to recent history-children ripped from their parents, a refugee crisis, inhuman detention centers, pedophile scandals-mirroring current TV news. There are, however, historical parallels for everything: history repeats itself, and Aunt Lydia knows it. Aunt Lydia knows that writing down the secrets of Gilead is dangerous, and yet she does it, though she cannot be sure her secrets are perfectly concealed:

[...] the stash of incriminating documents I've been hoarding for so many years will have featured not only at my own trial - should fate prove malicious, and should I live to feature at such a trial - but at the trials of many others. I've made it my business to know where the bodies are buried. (Atwood 2019, 61). 
She collects all the sins of Gilead along with her own and writes a memoir. I argue that Aunt Lydia's memoir is also a testimony in the sense used by Roy Perret, that is, "a literary work" written to "make sense" of a life and well as a "construction of a self-identity" (1996, 36). Atwood helps make sense of a historical and personally traumatic event.

\section{Putrid Breakfast, Undigested Porridge and Warm Milk}

Since The Testaments consists of testimonies-transcripts of Agnes's testimonies that read almost like diary entries, Aunt Lydia's confessions (and accusations), and Daisy's witness narrative-we learn not only about the strategies of power and ideological architecture of Gilead, but also about the day-to-day lives of individuals in it, including their meals. In Atwood's dystopian Gilead, the characters have minimal control over their lives and, consequently, over their meals: they cannot choose what to eat, cannot buy it themselves, and cannot cook it as they like or control portions. The uniformity of Gilead is represented not only by the citizens' uniforms and robes but also by the uniform food, which is unappetizing and limited. Moreover, Atwood shows that the regime metaphorically consumes its own citizens and uses images of cannibalism to expose the power hierarchy of Gilead in three witness narratives. Susannah Radstone argues that "it is witnessing that enables testimony, though what is witnessed may be the sheer impossibility of representing that which struggles towards, but refuses, representation" $(2001,62)$. Images of food in testimonies, I argue, enable Atwood to represent the ineffable and indigestible trauma of Gilead.

In The Handmaid's Tale, the Handmaids' diet of eggs and white meat illustrates their precarious status as privileged slaves and breeding machines (Sceats 2000, 111). Bodies in Gilead, especially the bodies of Handmaids, are reduced to reproductive functions. Similarly, Karen Stein sees the system as "dehumanizing and cannibalizing the victims" $(1996,67)$. This is mirrored by the food the Handmaids are allowed to eat: constant references to eggs suggest a parallel with producing a life, as well as the female body: "an eggcup on it, that kind that looks like a woman's torso, in a skirt. Under the skirt is the second egg, being kept warm" (Atwood 1996, 110). We are shown how the Handmaid's body is cut down and fragmented to her reproductive and consumable parts.

The Commanders' diet of red meat suggests high power and masculinity. However, even the Commanders do not get meat very often, which reminds readers that the regime controls and restricts even its most senior officials. Not even the Commanders' Wives can freely choose their food: they can only eat what the Handmaids buy for them and the Marthas in their kitchen cook for them. Gilead rations their portions, their time to eat and their food.

In Bite Me: Food in Popular Culture, Parasecoli points out food's centrality in "production, distribution and consumption, and providing fundamental institutions and customs" (2008, 64). The testimonies inform readers about Gilead's control over similar aspects of food: shopping, (queuing in shops, shortages), cooking and eating. In this sense, Atwood's fictional testimonies show a dystopia for everyone: all citizens are controlled by the system; they are all eating scarce, poor quality food that they have not chosen. 
Women in The Handmaid's Tale behave like enemies to one another, and the Marthas use what power they have to express their resentment: they serve undercooked or burnt food to the Handmaids, who must eat it. Kindness is rarely shown, although there are moments of (food-based) rebellion against the cold politics of Gilead. Atwood's ambiguous images of food function to ironize and subvert the ideology of the dystopian state. In Food: The Key Concepts, Belasco suggests, "food can obviously confine women to subservient roles, keeping them busy at home and 'quiet' in the public sphere" $(2008,44)$. Nevertheless, in Gilead the kitchen loses its significance as private space. The state controls (almost) every inch of its territory.

Atwood's dystopian novels show that food can be a means to communicate positive emotions of empathy, compassion, and support. Despite the stipulation of Gilead that Marthas "are not supposed to fraternize with [the Handmaids]" (Atwood 1996, 21), Rita, working in the kitchen, allows Offred to get an ice cube on a hot day, when she sees her in her warm red robe. The ice cube is not only a gesture of kindness but also a small act of rebellion against the ideology and strict dress-code of Gilead: "A shame, making you wear all them pillowcases on your head, in this weather" (Atwood 1996, 219). The kitchen and eating thus enable the characters to show (secretly) their humanity and human relationships.

This emerges again when the Marthas allow Agnes to help prepare food or show support for a pregnant handmaid or a sick wife in their house: "Marthas began fussing over [the Handmaid] and giving her bigger meals, and placing flowers in little vases on her breakfast trays" (Atwood 2019, 93). In The Handmaid's Tale, distrust and fear prevent women from bonding; however, in The Testaments, their friendships and sisterhood help destroy Gilead. Women show sympathy to each other by sharing food: "Becka would turn away, though she would slip me portions of her lunch when no one was looking" (Atwood 2019, 108). Gilead controls bonding between women but cannot eliminate it.

In Gilead, everything is political: bodies, intimate thoughts and food. Dystopian food is scarce and limited because of shortages. For Easter, Aunt Lydia allows eggs to be dyed baby pink and baby blue: "You have no idea what delight this brings [...] Our diet is monotonous and a little variation is welcome, even if only a variation in colour" (Atwood 2019, 33). The Aunts eat a restricted, repetitive diet of eggs, sandwiches and indeterminate soups. Only when Daisy becomes one of the Pearl Girls and comes to Ardua Hall do we realize just how unappetizing their food is. The Gilead girls are used to it, so indoctrinated that they repeat learned phrases such as "Be thankful for what you are given" and "It's disrespectful not to finish" (Atwood 2019, 323). The outsider Daisy, however, can recognise leftovers and nauseating scraps, and she rebelliously names the dishes "mouldy dishwater" and "fish eyes in glue" (Atwood 2019, 323). Her testimony gives us a taste of bitter Gilead.

\section{Eating Cakes and Girls}

Citizens of Gilead, especially women and girls, are often portrayed as food to show that they are being consumed by their husbands and/or commanders. Agnes describes herself as a pastry: "I had a dough face, like the cookies [...] with raisin eyes and pumpkin-seed teeth" (Atwood 2019, 11). Atwood uses metaphors of cooking and eating to underline the low position of women in the hierarchy. The regime manipulates individuals through discipline 
regimes of deprivation and luxury, as in the case of Aunt Lydia, who is tempted by luxury food like fruit and salmon: "it was like a recipe for tough steak: hammer it with a mallet, then marinate and tenderize" (Atwood 2019, 170). To feel control, even a young girl like Agnes turns to metaphors of baking: "I would make a man out of dough, and they would bake it in the oven [...] I always made dough men, I never made dough women, because after they were baked I would eat them, and that made me feel I had a secret power over men" (Atwood $2019,20)$. It is not only girls who are depicted as food items; even people with some power, including Aunts, are presented as edibles: "She smiled. It was like an old turnip smiling: the dried-up kind our Marthas used to put in soup stock" (Atwood 2019, 247). Images of fragmented bodies and faces underline the fact that Gilead is a failed utopia for everyone.

However, on rare occasions, Gilead tolerates traditional party food, including cake and whipped cream. Daisy's birthday in Canada and a Gileadean Birth Day offer similar food: whipped cream and cake. But there is something you cannot get in Gilead: ice-cream. Aunt Beatrice, who takes Daisy to Gilead, wonders why there is no ice cream in Gilead: "I honestly don't see what's wrong with ice cream, as long as it has no chemicals" (Atwood 2019, 270).5 Offred also recollects the ice cream of pre-Gileadean times. She nostalgically associates the past with the freedom to choose her own food, healthy or unhealthy. She could even treat herself and her daughter to indulgent food, like ice cream, which she recalls not by the name but by the colour. However, Gilead is not colourful; it is grey and unforgiving. In Carnal Appetites, Elspeth Probyn argues that "[i]n eating, pleasure offers itself to be problematised. As it brings our senses to life, it also forefronts the viscerality of life" $(2000,7)$. This might be why Gilead forbids ice cream; it brings pleasure but also brings up deep feelings that might be uncontrollable and subversive.

Alcohol has a similarly subversive potential, and it is thus a strictly controlled substance in oppressive Gilead. Lupton points out that the consumption of alcohol "signals escape from the civilized body into self-indulgence and physical and emotional release" (1996, 32). The tyrannical regime of Gilead gives the citizens measured and controlled moments of liberation. On special occasions, the privileged levels of Gileadean society-Commanders and their Wives-can drink alcohol, especially on a Birth Day. Aunt Lydia is also permitted to drink a teaspoon of rum in her coffee when she visits Commander Judd. Aunt Lydia is a double agent, appearing to serve Gilead while scheming to bring it down: "we lifted our mugs, clinked them together" (Atwood 2019, 282). This gesture reminds her of preGileadean times, before coffee became "a valuable commodity that is increasingly difficult to obtain" (Atwood 2019, 173).

Even such senior women as Aunts Lydia, Vidala, Elizabeth, and Helena, the women responsible for inventing laws, uniforms, names, and hymns, can only drink coffee at their occasional meetings with Commander Judd. Traditionally, as Lupton argues, "coffee [...] was represented as a stimulant, preparing individuals for the day ahead" (1996, 35-6); here it stimulates them to think about how they have betrayed their former education, values and lifestyles. Drinking coffee with Commander Judd is the epitome of this two-faced behaviour.

5 Aunt Beatrice's line might contain the seeds of Atwood's ironic food joke: many a reader will be reminded that most ice cream we normally eat contains a great deal of chemicals. 
Coffee is also a symbol of life outside Gilead. On their escape to freedom, Daisy and Agnes stop at a border store and buy two cups of coffee: "The coffee must have been sitting around all day because it was the worst I'd ever tasted" (Atwood 2019, 363). But coffee definitely tastes of freedom. ${ }^{6}$

Atwood associates certain foods with freedom. ${ }^{7}$ Although officially Gilead provides food for everyone, and nobody is hungry, their food is unsatisfying because the people are hungry for freedom. This is illustrated by the terrible hunger pangs the girls experience on their way to Canada, when smuggling evidence against Gilead. On arrival, they are given their first taste of freedom: tea and sandwiches, which are described as "cheese, but it wasn't Gilead cheese, it was real cheese: goat cheese with chives" (Atwood 2019, 378). Just as Gilead itself is fake, rotten and corrupt, so is its cheese is artificial and sickening.

Because of (wartime) food shortages, Gilead feeds bad food and even food substitutes to its citizens as we find in the testimonies. Ersatz Gileadean cheese thus becomes the epitome of everything that is disgusting in the dystopian regime of fake food, fake relationships and fake religion. ${ }^{8}$ Agnes cannot digest the truth about her mother being a Handmaid; she spits out a mouthful of ersatz cheese sandwich: "While telling me this story, Shunammite was continuing to chew. I watched her mouth, out of which my doom was emerging. There was orange cheese substitute between her teeth" (Atwood 2019, 85). On the other hand, Zilla (a Martha) helps her to accept this truth by giving her a hot biscuit with honey. Our emotions and tastes are connected. According to Emma Parker, the mouth is "the site of ingestion of both food and feelings" (1995, 359). A sweet taste helps Agnes to stomach her bitter feelings of disgust.

\section{Food and Human Sacrifice}

Since Gilead is a theocratic regime, religion plays an important role in the lives and politics of its citizens, The Testaments shows food as sacrifice and offering: "Blood was polluting, especially when it came out of girls, but God once liked having it spilled on his altars. Though he had given that up [...] in favour of fruits, vegetables, silent sufferings, and good deeds" (Atwood 2019, 83). Women leave food items at the statue of Aunt Lydia, associating her with divine powers: "Votaries have taken to leaving offerings at my feet: eggs for fertility, oranges to suggest the fullness of pregnancy, croissants to reference to the moon" (Atwood 2019, 4). God has given up blood sacrifice, but Gilead has not: it sacrifices women's bodies for babies.

The woman's body bleeding on the table evokes the imagery of sacrifice: the state of Gilead sacrifices the Handmaids to give life. There is another association between a woman's body

$6 \quad$ Atwood might have been inspired by Mormon church food regulations and the Mormons' prohibition of coffee and tea; this was not just because of caffeine but also because of a 19th-century fad about high food and drink temperatures affecting the moral disposition. See a recent article on this "'Always ask if there is coffee in it:' Mormon church stands by rule with new advice" by Edward Helmore (2019).

As an example of a link between freedom and junk food, Lupton points to a junk food advertisement which ends in "a challenge to the reader to reject 'Big Brother' and seek independence" (Lupton 1996, 147). Gilead's restrictive puritanical politics is opposed to freedom to indulge and pleasure.

8 Many of Atwood's food references are ironic. The average consumer in Canada and elsewhere in North America accepts a great deal of fake cheese and other synthetic foodstuffs. (In fact, many Canadian consumers prefer synthetic maple syrup to real maple syrup.) 
and food (women not only prepare food but also produce 'food' during pregnancy and lactation). In Holy Feast and Holy Fast: The Religious Significance of Food to Medieval Women, Caroline Walker Bynum argues "like body, food must be broken and spilled forth in order to give life. Macerated by teeth before it can be assimilated to sustain life, food mirrors and recapitulates both suffering and fertility" $(1988,30)$. In the same way, the bodies of the Handmaids are broken and degraded to be consumed. Their bodies are sacrificed to bring life to Gilead, to bring children. An extreme case is shown in The Testaments, when Ofkyle is sacrificed for the Commander's baby. She dies in childbirth, bleeding to death without medical attention because the doctor is called too late. Agnes shows deep sympathy: "I uncovered her face. It was flat white: she must have no blood left in her" (Atwood 2019, 103). In a typically Atwoodian scene, the Handmaid's gutted corpse is juxtaposed with the leftover party food of the Marthas, who eat cake and white-bread sandwiches with the crusts cut off. Agnes, deeply touched by Ofkyle's death (and recognizing her possible future and the monstrosity of Gileadean misogyny), cannot eat. The Marthas seem untroubled by Gilead's choice to save the child not the Handmaid.

On the other hand, The Testaments includes scenes of women helping each other, forming strong alliances to protect one another. Aunt Lydia, while appearing to be dedicated to the regime, orchestrates the most important act of women's solidarity when she plans the exfiltration of evidence of corruption and human rights abuses in Gilead. She also protects young girls from Commander Judd, a pedophile and murderous, Bluebeard figure, who has married a series of young girls and poisoned them in turn to get a new, possibly younger bride. Aunt Lydia discovers that he plans to use rat poison to get rid of his latest wife and arranges for the young woman to go on a retreat to the Calm and Balm Clinic. In Gilead, medical treatment is strictly controlled, and a woman needs permission from her husband to get it. Aunt Lydia saves the young bride; she helps the two girls to leave Gilead for Canada, smuggling the evidence of the regime's corruption.

Testimonies illustrate the relation between consumption and power, while simultaneously showing that women can regain the right to eat, cook their own food, or indulge in ice-cream and coffee. The Gileadean narratives show how the state portions and poisons women. By revealing how consumption is related to such power politics, Atwood's witnesses learn to recognize that the rules and restrictions under which they live are dystopian, unsatisfying and sickening, and then develop the skills to resist them. Seeing through the state ideology of (false) utopia is an important step.

\section{Conclusion}

Food choices, then, can show not only the characters' preferences and individual personalities but also their weaknesses. Even in a state that controls every bite its citizens eat, people still try to retain some control over their lives and deaths, as some women attempt to commit suicide by refusing to eat, or by eating something inedible, such as drain cleaner. Aunt Lydia, Agnes and Daisy include their eating habits in their testimonies because these illustrate the dystopian and hostile atmosphere of Gilead; this article has illuminated some of the important ways food is deployed throughout The Testaments to anchor the contrasting story-telling techniques 
and individual perspectives layered in the transcripts of witness testimony. These testimonies depict food shortages, rationing and problems with the food distribution in an oppressive regime that would never admit any problems with food. The testimonies also feature images of disgusting and unsatisfying food, which function as literal and metaphorical depictions of the citizens' hunger for freedom and resistance to the restrictive state. Atwood uses specific images of food, associating these with women (eggs, chicken, white meat, biscuits) to show the gender hierarchy and dehumanizing sexual policy of Gilead.

Atwood's testimonies of dystopia in the two Gilead novels do not simply imitate witness narratives to make Gilead more believable. A polyvocal, multi-generic, multi-perspectival novel like The Testaments draws attention to the form of witness literature. Because of the implicitly hybrid form of testimony, the text cannot be a monological or mimetic representation of (fictional) traumatic events in oppressive regimes. Rather, it shows the paradoxes of narrating trauma, and questions what seems to be fixed and authoritative, whether the Gileadean version of religion, and gender roles, or hunger and what can and cannot be consumed. Atwood uses the genre of testimony to write beyond genre and beyond history.

\section{References}

Ackew, Emily. 2019. "Why it took Margaret Atwood 30 years to find the right voice for a sequel to The Handmaid's Tale." ABC News, September 17, 2019. https://www.abc.net.au/news/2019-09-17 /margaret-atwood-the-testaments-handmaids-tale-sequel/11519710.

Arnold, Bill T., and Hugh G. M. Williamson. 2005. Dictionary of the Old Testament: Historical Books. Nottingham: InterVarsity Press.

Atwood, Margaret. (1982) 1995. Second Words: Selected Critical Prose 1960-1982. Toronto: House of Anansi Press.

-. (1985) 1996. The Handmaid's Tale. London: Vintage.

- 2017. "Margaret Atwood on What The Handmaid's Tale Means in the Age of Trump." The New York Times, March 10, 2017. https://www.nytimes.com/2017/03/10/books/review/margaret-atwoodhandmaids-tale-age-of-trump.html.

—. 2019. The Testaments. London: Chatto \& Windus.

Belasco, Warren. 2008. Food: The Key Concepts. Oxford, New York: Berg.

Burrell, Kathy. 2003. "The Political and Social Life of Food in Socialist Poland." Anthropology of East Europe Review, 21 (1): 189-95. https://scholarworks.iu.edu/journals/index.php/aeer/article/view/377/452.

Bynum, Caroline Walker. 1988. Holy Feast and Holy Fast: The Religious Significance of Food to Medieval Women. Berkeley, Los Angeles, London: University of California Press.

Christou, Maria. 2017. Eating Otherwise: The Philosophy of Food in Twentieth-Century Literature. Cambridge: Cambridge University Press.

Counihan, Carole M. 1999. The Anthropology of Food and Body: Gender, Meaning and Power. New York and London: Routledge.

Counihan, Carole M., and Steven L. Kaplan, eds. 1998. Food and Gender: Identity and Power. Taylor and Francis.

Feldman, Lucy. 2019. "Let's Break Down the Most Mysterious Parts of The Testaments, With a Little Help from Margaret Atwood." Time, September 10, 2019. https://time.com/5673535/the-testaments-plotquestions-margaret-atwood/.

Felman, Shoshana, and Dori Laub. 1992. Testimony: Crises of Witnessing in Literature, Psychoanalysis, and History. New York and London: Routledge.

Gelfert, Axel. 2014. A Critical Introduction to Testimony. London: Bloomsbury. 
Genette, Gérard. 1997. Palimpsests: Literature in the Second Grade. Translated by Channa Newman and Claude Doubinsky. Lincoln: University of Nebraska Press.

Helmore, Edward. 2019. "'Always ask if there is coffee in it': Mormon Church stands by rule with new advice." The Guardian, August 16, 2019. https:/www.theguardian.com/us-news/2019/aug/16/alwaysask-if-theres-coffee-in-it-mormon-church-stands-by-rule-with-new-advice.

LaCapra, Dominic. 2014. Writing History, Writing Trauma. Baltimore: Johns Hopkins University Press.

Langer, Lawrence L. 1993. Holocaust Testimonies: The Ruins of Memory. New Haven: Yale University Press.

Luhmann, Susanne. 2018. "Managing Perpetrator Affect: The Female Guard Exhibition at Ravensbrück." In Perpetrating Selves, edited by Clare Bielby and Jeffrey Stevenson Murer, 247-269. Cham: Palgrave Macmillan. https://doi.org/10.1007/978-3-319-96785-1_12.

Lupton, Deborah. 1996. Food, the Body and the Self. London, Thousand Oaks, New Delhi: Sage Publications.

Parasecoli, Fabio. 2008. Bite Me: Food in Popular Culture. Oxford and New York: Berg.

Parker, Emma. 1995. "You Are What You Eat: The Politics of Eating in the Novels of Margaret Atwood." Twentieth Century Literature 41 (3): 349-68. https://doi.org/10.2307/441857.

Perrett, Roy W. 1996. "Autobiography and Self-Deception: Conjoining Philosophy, Literature, and Cognitive Psychology.” Mosaic: An Interdisciplinary Critical Journal 29 (4): 25-40.

Probyn, Elspeth. 2000. Carnal Appetites: FoodSexIdentities. London and New York: Routledge.

Radstone, Susannah. 2001. "Social bonds and psychical order: Testimonies." Cultural Values 5 (1): 59-78. https://doi.org/10.1080/14797580109367221.

Sceats, Sarah. 2000. Food, Consumption, and the Body in Contemporary Women's Fiction. Cambridge: Cambridge University Press.

Stein, Karen. 1996. "Margaret Atwood's Modest Proposal: The Handmaid's Tale." Canadian Literature 148: 57-73. https://canlit.ca/article/margaret-atwoods-modest-proposal/.

Wolfreys, Julian. 2015. “Trauma, Testimony, Criticism: Witnessing, Memory and Responsibility." In Introducing Criticism in the $21^{\text {st }}$ Century, edited by Julian Wolfreys, 126-48. Edinburgh: Edinburgh University Press. 